\title{
The radiological report... and then what?
}

\section{Il referto.... e poi?}

\section{E. Comino}

Servizio Radiologico CIDIMU, Via Legnano 23, 10128 Torino, Italy

Correspondence to: E. Comino, Corso Re Umberto 141, 10134 Torino, Italy, Tel.: +39-011-3181211, e-mail: mariacom@tiscalinet.it

Received: 8 October 2010 / Accepted: 18 November 2010 / Published online: 10 July 2011

(C) Springer-Verlag 2011

\begin{abstract}
The radiology report has always been considered as "the most important step in the clinical radiological act". While agreeing with this concept, the author emphasises that the report can in no way replace the duty to communicate with the patient, as mentioned in Art. 31, Italian Code of Medical Ethics. Italy aside, this issue has been thoroughly investigated and debated abroad since the 1970s and, in the past as well as more recently, many interesting contributions have been published both on the need for verbal communication, particularly in certain settings, and on the best manner to approach this task. A recent book published in Italy also provides useful advice in this regard. The author hopes that in Italy, as in other countries, an extensive debate will give rise to a fuller awareness of the issue, thereby providing a range of shared solutions.
\end{abstract}

Keywords Radiological report · Patient-doctor communication

\section{Riassunto}

Il referto radiologico è stato considerato da sempre il "momento più significativo dell'atto clinico radiologico". L'autore, pur concordando con tale concetto, sottolinea che il referto non esaurisce in alcun modo il dovere di comunicare con il paziente, come ricordato dall'art. 31 del Codice Deontologico italiano. A differenza che in Italia, all'estero questo problema è stato ampiamente approfondito e dibattuto fin dagli anni '70 e sono stati presentati, in passato come recentemente, numerosi interessanti contributi riguardanti sia la necessità del colloquio verbale specie in determinate circostanze, sia le migliori modalità di esecuzione del colloquio stesso. Anche un recente libro italiano fornisce utilissimi consigli a questo proposito. L'autore si augura che anche in Italia un ampio dibattito sull'argomento possa far nascere una migliore presa di coscienza del problema fornendo quindi soluzioni possibili e condivise.

Parole chiave Referto radiologico · Comunicazione medico-paziente

\section{Introduction}

Not so long ago, Francesco Dalla Palma, at the time president of the Italian Society of Medical Radiology, stated that the major product of the radiologist's profession is the report, which represents the most significant step in the clinical radiological act. At the same time, several publications (mostly by Francesco Schiavon) and a large number of conferences extensively discussed the radiology report with the laudable aim of standardising its features and, more importantly, of avoiding omissions or errors.

This attention surrounding the report tended, however, to

\section{Introduzione}

In un passato abbastanza recente, l'allora nostro presidente Francesco Dalla Palma affermava che "la completa realizzazione della professione del radiologo trova la sua massima espressione nel referto che rappresenta il momento più significativo dell'atto clinico radiologico". Contemporaneamente, numerosi scritti (merito soprattutto di Francesco Schiavon) e ancor più numerosi convegni approfondivano in ogni dettaglio il referto con il lodevole scopo di uniformarne le caratteristiche e soprattutto di evitare omissioni o errori. 
obscure the indisputable fact that the report does not in any way fulfil the duty of the physician, and therefore of the clinical radiologist, to communicate with the patient, as we are reminded in Art. 33 of our latest Code of Medical Ethics, which states that "the doctor must provide the patient with the most appropriate information ... taking into account his or her ability to understand ...".

Unfortunately, the tradition of face-to-face communication between the radiologist and the patient was lost in the 1960s as a result of a series of objective factors but also, in my opinion, as a result of new cultural attitudes that I now attempt to delineate. The first reason is the expansion of health care, which has dramatically increased the number of radiological procedures; second, the emergence of the radiology technician, an allied profession that has often deprived us of direct contact with the patient; third, the development of new technologies (computed tomography, ultrasound, interventional radiology and magnetic resonance imaging), which has further expanded the commitments and responsibilities of the radiologist, taking up more time and making communication with the patient increasingly infrequent and difficult.

In addition, the idea has taken hold that it is not essential for the radiologist to communicate with the patient (now that specialist medicine prioritises communication with the general practitioner or the referring specialist), in part because the radiologist may not know the patient and does not know how he or she might react to bad or worrying news. The radiologist may also be afraid to say too little or too much, perhaps causing embarrassment to the general practitioner or specialist, and may think that the patient would prefer to have the diagnosis communicated and explained by someone else.

Finally, today's radiologists are not always adequately trained to communicate with patients or explain a report, being used to maintaining a certain detachment and concentrating on the accuracy and completeness of the diagnosis; they have long had an almost ancillary status with respect to clinicians to whom the patients refer for interpretation of the report when not of the images themselves.

This forced association between the report and its communication has meant that in Italy, apart from sporadic mention by a few influential authors [1-4], the question of the desirability or even the need for the radiologist to communicate verbally the results of radiological examinations to patients has never been addressed. Abroad, however, this issue began being debated before the 1980s, especially in the English-language literature. The first contribution bringing radiologists' attention to the increasing lack of information to patients with regard to examination results was the famous and much-quoted editorial by Berlin [5] in 1977, titled "The radiologist: doctor's doctor or patient's doctor?" At the latest European Congress of Radiology
Questa attenzione concentrata sul referto metteva però in ombra il fatto, incontestabile, che il referto non esauriva in alcun modo il dovere del medico, e quindi anche del medico radiologo, di comunicare con il paziente, come ci viene ben ricordato dall'art. 31 del nostro più recente Codice Deontologico che recita appunto "il medico deve fornire al paziente la più idonea informazione... tenendo conto delle sue capacità di comprensione...".

Purtroppo, l'abitudine al dialogo fra il medico radiologo ed il paziente si è perduta negli anni '60 per una serie di fattori oggettivi, ma anche, a mio modesto parere, per nuovi atteggiamenti culturali che cercherò ora di ricordare. Anzitutto, l'estendersi dell'assistenza sanitaria che ha moltiplicato vertiginosamente gli esami radiologici; poi, la comparsa della nuova figura professionale del tecnico di radiologia che ci ha privato sovente del contatto diretto con $i$ pazienti; in seguito, l'affermarsi delle nuove tecnologie (tomografia computerizzata, ecotomografia, radiologia interventistica, risonanza magnetica) che ha ancora dilatato gli impegni e le responsabilità del medico radiologo impegnandone sempre più il tempo e rendendo sempre più difficile e raro il colloquio.

Oltre a ciò, si è fatto strada negli anni il concetto che non sia compito essenziale del medico radiologo comunicare con il paziente (ormai la medicina specialistica considera prioritaria la comunicazione con il medico di base o quantomeno inviante), anche perché il medico radiologo non lo conosce o quasi e non sa come potrebbe reagire ad una notizia cattiva o anche solo inquietante, ha inoltre paura di dire troppo o troppo poco mettendo forse in difficoltà il curante o un altro specialista e talora pensa che il paziente stesso preferisca ricevere da altri la comunicazione della diagnosi e le spiegazioni ad essa legate.

Infine, il medico radiologo è oggi non sempre adeguatamente preparato a dialogare con il paziente o anche solo a spiegare adeguatamente un referto, è abituato a mantenere un certo distacco dal paziente occupandosi di più dell'esattezza e della completezza della diagnosi, mantiene da tempo una condizione quasi ancillare nei confronti del clinico al quale il paziente si rivolge per interpretare il referto quando non le stesse immagini.

La forzata identificazione fra referto e comunicazione ha fatto sì che in Italia, tranne pochi cenni di pochi autorevoli autori [1-4], non fosse mai affrontato il problema dell'opportunità o forse della necessità della comunicazione verbale ai pazienti dei risultati delle indagini radiologiche. All'estero, invece, soprattutto nella letteratura anglo-americana, se ne scriveva già prima degli anni '80. Il primo articolo che pose all'attenzione dei medici radiologi la sempre crescente disinformazione dei pazienti sui risultati delle loro indagini fu il celebre, citatissimo, editoriale di Berlin [5] del 1977, dal titolo "The radiologist: doctor's doctor or patient's doctor?" E nel più recente European Congress 
(more than 30 years later!) the same author again took up and developed what he wrote back in 1977.

The numerous papers that followed mainly concerned the two basic aspects of communication: "if and why" and "how". According to several authors, the question remains open: the ethical and deontological requirement for communication is not in question (and improved communication can help avoid malpractice litigation), whereas the controversy remains as to whether it should be the radiologist to communicate with the patient and whether this is indeed what the patient wants [6-10]. Other authors, following surveys conducted both in Europe and the United States, show that about $90 \%$ of patients want to hear the results of imaging investigations directly from the radiologist in all cases, whereas the remaining $10 \%$ want this done only following an explicit request. Only $50 \%$ of referring physicians, however, want the radiologist to communicate directly with the patient. However, this percentage increases considerably (to around 70\%) when the condition is serious or urgent [11-17]. Other, especially French, authors have taken for granted the need for verbal communication with the patient to explain the procedures and have moved on to analyse the various possibilities and opportunities of verbal communication [18-26], dispensing many - at times interesting but often obvious - suggestions and providing some protocols [Costruire, Réaliser, Ecouter, Donner informations, Organiser (CREDO), Partnership, Excuses (Apology), Respect, Legitimization, Empathy, Support (PERLES), Setting up, Perception, Invitation, Knowledge, Emotions, Strategy (SPIKES)] to improve and standardise communication.

What happens in Italy? There are few who deny the right of patients to be informed of the results of imaging procedures, whereas many (in varying percentages according to the subspecialty), for reasons of time and work organisation, overlook this right and consider the report as the only required form of communication. To better assess the situation and determine whether and to what extent patients receive verbal communication of the results of procedures in addition to the written report, a brief survey was conducted in the diagnostic imaging unit of a public hospital and a noncontracted private clinic. The question put to my colleagues was: "Was the patient informed verbally of the results of the procedure? If yes, please specify whether the information was conveyed using a few quick and generic words or via a complete and comprehensive report." The results are presented in Tables 1 and 2 .

As can be seen, the difference between the two situations is substantial as far as conventional radiology is concerned, where the constant and predominant presence of the radiology technician makes any communication with the radiologist almost impossible; this is much less the case for all the other imaging modalities. The difference between of Radiology (dopo più di trent'anni!) lo stesso autore ha ripreso e potenziato quanto scritto allora.

I successivi, numerosissimi, articoli presero essenzialmente in esame $i$ due aspetti fondamentali della comunicazione: "se e perché" e "come". Secondo i diversi autori il problema rimane aperto: l'esigenza etica e deontologica della comunicazione non è in discussione (e la maggiore comunicazione pù̀ mettere al riparo dalle denunce per malpractice), mentre permane controversa l'opportunità che sia proprio il medico radiologo a parlare e che sia proprio questo che i pazienti desiderano [6-10]. Altri autori, a seguito di indagini svolte in nazioni europee e negli Stati Uniti, hanno dimostrato che circa il 90\% dei pazienti desidera che il medico radiologo comunichi loro sempre l'esito degli esami, mentre il restante $10 \%$ lo desidera solo a seguito di un'espressa richiesta. Solo il $50 \%$ dei medici curanti desidera invece la comunicazione verbale al paziente da parte del medico radiologo, ma la percentuale aumenta considerevolmente (circa il 70\%) quando si tratta di situazioni gravi o urgenti [11-17]. Ancora altri autori, specie francesi, considerata come acquisita la necessità del colloquio con il paziente per la spiegazione degli esami, hanno analizzato le diverse e le migliori possibilità ed opportunità della comunicazione verbale [18-26] dispensando numerosi, talora interessanti ma sovente scontati consigli e fornendo anche alcuni protocolli standard (Construire, Réaliser, Ecouter, Donner informations, Organiser [CREDO], Partnership, Excuses (Apolology), Respect, Legitimization, Empathy, Support [PERLES], Setting up, Perception, Invitation, Knowledge, Emotions, Strategy [SPIKES]) per migliorare e standardizzare il colloquio stesso.

Cosa avviene in Italia? Sono ormai pochi quelli che negano il diritto da parte dei pazienti di essere informati sui risultati delle indagini di diagnostica per immagini, mentre sono moltissimi (in diversa percentuale a seconda delle sub-specialità) che per ragioni di tempo e di organizzazione del lavoro non ne tengono alcun conto e considerano il referto la sola forma dovuta di comunicazione. Al fine di meglio verificare la situazione, è stata condotta una breve inchiesta nel servizio di diagnostica per immagini di un ospedale pubblico e di un poliambulatorio privato non convenzionato al fine di verificare se ed in quale misura $i$ pazienti ricevevano, oltre al referto scritto, una comunicazione verbale sui risultati degli esami. La domanda formulata al collega era questa: è stata data al paziente una comunicazione verbale sull'esito dell'esame? In caso positivo si doveva precisare se tale comunicazione era stata fornita con poche rapide e generiche parole (A) oppure con una completa ed esauriente relazione (B). I risultati sono presentati nelle Tabelle 1 e 2.

Come si può osservare, la differenza fra le due situazioni è sensibile per quanto riguarda la radiologia tradizionale, dove la costante e prevalente attività del tecnico radiologo 
Table 1 "San Giovanni Bosco" Public Hospital, Turin, Italy

\begin{tabular}{llll}
\hline \multirow{2}{*}{ Modality } & \multirow{2}{*}{ No, \% } & \multicolumn{2}{c}{ Yes, \% } \\
\cline { 3 - 4 } & & A & B \\
\hline Conventional radiology & 95 & & 5 \\
Mammography (screening) & 70 & & 30 \\
CT & 82 & & 18 \\
MRI & 54 & 13 & 33 \\
US & & 60 & 40 \\
\hline
\end{tabular}

$C T$, computed tomography; $M R I$, magnetic resonance imaging; US, ultrasound

Tabella 1 Ospedale San Giovanni Bosco (Torino)

\begin{tabular}{llll}
\hline Metodica & \multirow{2}{*}{ No, \% } & \multicolumn{2}{c}{ Si, \% } \\
\cline { 3 - 4 } & & $A$ & $B$ \\
\hline Radiologia tradizionale & 95 & & 5 \\
Senologia (screening) & 70 & & 30 \\
$T C$ & 82 & & 18 \\
$R M$ & 54 & 13 & 33 \\
ECT & & 60 & 40 \\
\hline
\end{tabular}

$T C$, tomografia computerizzata; $R M$, risonanza magnetica; ECT, emission computed tomography

giving "short and generic" and "complete and comprehensive" information seems to be largely related to the complexity and severity of the condition diagnosed and, to some extent, the subjective impression of the radiologist. The brief survey showed, however, that in the most serious cases, verbal communication usually does take place.

Nothing can be said with regard to the quality of the verbal communication, if not to restate that the radiologist is not always sufficiently trained to communicate with patients, given that this tradition has been long lost, and radiology specialty schools offer no opportunity for communication and do not (yet?) teach doctor-patient communication techniques, there being no conviction that this is either useful or necessary.

A recent and highly recommended book by De Santi and Simeon [27] suggests the characteristics of ideal consultation, lasting not less than $10 \mathrm{~min}$ ! Here is a summary:

1. Preparation: be motivated and know what the patient wants to know;

2. Welcome: the setting, privacy, the possible assistance of a family member, listening (patients usually ending what they have to say in $92 \mathrm{~s}$ );

3. Information: supplied gradually and simply, leaving room for other questions and respecting what the patient does not want to know, to the point of reaching - if possible - the diagnosis;
Table 2 CI. DI. MU., private clinic, Turin, Italy

\begin{tabular}{llll}
\hline \multirow{2}{*}{ Modality } & \multirow{2}{*}{ No, \% } & \multicolumn{2}{c}{ Yes, \% } \\
\cline { 3 - 4 } & & A & B \\
\hline Conventional radiology & 36 & 46 & 18 \\
Mammography (screening) & & 90 & 10 \\
CT & \multirow{2}{*}{35} & 30 & 70 \\
MRI & & 30 & 35 \\
US & & 100 \\
\hline
\end{tabular}

$C T$, computed tomography; $M R I$, magnetic resonance imaging; $U S$, ultrasound

Tabella 2 Poliambulatorio CI DI MU (Torino)

\begin{tabular}{lccc}
\hline Metodica & \multirow{2}{*}{ No, \% } & \multicolumn{2}{c}{ Sì, \% } \\
\cline { 3 - 4 } & & $A$ & $B$ \\
\hline Radiologia tradizionale & 36 & 46 & 18 \\
Senologia (screening) & & 90 & 10 \\
TC & & 30 & 70 \\
RM & 35 & 30 & 35 \\
ECT & & & 100 \\
\hline
\end{tabular}

$T C$, tomografia computerizzata; $R M$, risonanza magnetica; ECT, emission computed tomography

rende quasi impossibile il colloquio con il medico; lo è assai meno per tutte le altre metodiche. La differenza segnalata fra il colloquio breve e generico e quello più dettagliato e completo sembra in gran parte legata alla complessità e gravità della patologia riscontrata e in qualche misura anche all'impressione soggettiva del medico radiologo. $\grave{E}$ apparso comunque evidente che nei casi di maggiore gravità il colloquio verbale di solito avviene.

Non è possibile alcuna considerazione a proposito della qualità del colloquio, se non ribadendo che il medico radiologo non è sempre sufficientemente preparato a parlare con il paziente: se ne è da tempo perduta la tradizione, le scuole di specializzazione non ne evidenziano anche solo l'opportunità e non insegnano (ancora?) le migliori modalità del colloquio stesso, fa difetto la convinzione che sia davvero utile e necessario.

Un recente e consigliabilissimo libro italiano di De Santi e Simeoni [27] suggerisce le caratteristiche di un colloquio ideale, della durata non inferiore a 10 minuti! Eccone una sintesi:

1. preparazione: essere motivati e conoscere quanto il paziente vuole sapere;

2. accoglienza: $i$ locali, la privacy, l'eventuale assistenza di un familiare, l'ascolto (di solito il paziente conclude il suo discorso in 92 secondi);

3. informazione: in maniera graduale e semplice, lasciando 
4. Support: not only describing the subsequent diagnostic and therapeutic procedures, but also covering the benefits and possible risks, and a general assessment of the prognosis;

5. Conclusion: a friendly goodbye with the offer of further consultations and a telephone number.

Such an ideal consultation is no doubt difficult, if not impossible, to carry out but, without succumbing to the easy temptation of thinking that it is the duty of clinicians only, certain - perhaps necessary - considerations need to be made, such as:

- verbal communication with patients is always appropriate and sometimes indispensable (in severe cases and emergencies);

- the fact that the referring physician may object to this activity does not exempt us from this duty;

- the real problem is mainly to find the time and to acquire and maintain the best possible level of preparation.

\section{Preparation}

This is based on two premisses: the first, concerning the radiologist's personally, is that the consultation should be considered as an integral part of the examination and not as an added "extra" to be granted only under certain circumstances; the other is to ensure that the patient understands that this consultation is his or her right and may prove very useful. The Italian Society of Medical Radiology is finally moving in this direction, as shown by the two illustrations (appropriately captioned) that recently appeared in the society's journal and on the Web site (Figs. 1 and 2). It is also essential to:

- humbly read books or magazines that can help to adapt verbal communication to the patient;

- write down patients' questions (which are often very similar) to prepare appropriate answers;

- discuss the issue with colleagues and encourage lessons, courses and discussions on the subject.

\section{Time}

This is the main problem with one major premiss: it is clear that the radiologist rarely has the time or opportunity to talk to every patient, and this often imposes the difficult choice of whether to say very little to everyone (or almost everyone) or something in depth to those who need it most. But which patients have the most need for verbal communication? Apart from the more serious and urgent cases, it is very difficult - if not impossible - to distinguish those who want to listen and talk from those who cannot wait to get back to their own doctor to talk to him or her, bearing in spazio ad altre domande del paziente e rispettando quanto non vuole sapere fino a giungere - se possibile alla diagnosi;

4. supporto: non solo un successivo iter diagnostico-terapeutico, ma anche vantaggi e rischi possibili con un generico giudizio prognostico;

5. conclusione: un saluto amichevole, la possibilità di un ulteriore colloquio, un numero di telefono.

Un colloquio ideale come quello proposto è certamente difficile e forse impossibile da realizzarsi, ma senza cedere alla comoda tentazione di pensare che sia solo compito dei clinici sono possibili e forse doverose alcune considerazioni:

- è sempre opportuno e talora indispensabile (casi gravi, urgenze) il colloquio verbale con i nostri pazienti;

- il fatto che non sempre il curante lo desideri non ci esime da questo dovere;

- il vero problema è anzitutto quello di trovare il tempo e poi di avere e mantenere la migliore preparazione.

\section{La preparazione}

Sono necessarie due premesse: la prima, che riguarda personalmente il medico radiologo, è quella di considerare il colloquio verbale come parte integrante dell'esame e non come un di più che può essere concesso solo in determinate circostanze e l'altra è quella di far comprendere al paziente che tale colloquio è un suo diritto e può essere per lui di grande utilità. In questa direzione si muove finalmente la Società Italiana di Radiologia Medica (SIRM) con le due illustrazioni (con appropriato commento) recentemente apparse sulla rivista e nel sito societario (Figg. 1 e 2).

\section{$\grave{E}$ indispensabile inoltre:}

- leggere con umiltà qualche libro o rivista che possa aiutare nell'approccio verbale con il paziente;

- annotarsi le domande dei pazienti (sovente del tutto simili) per avere pronte adeguate risposte;

- discuterne con $i$ colleghi e sollecitare lezioni, corsi e dibattiti sull'argomento.

\section{Il tempo}

È il principale problema con una sola importante premessa: è evidente che ben raramente si ha il tempo e quindi la possibilità di parlare con tutti e sovente si imporrà la diffcile scelta se dire poco a tutti (o quasi) o qualcosa di più a chi ne ha maggiormente bisogno. Ma quale paziente ha maggiore bisogno del colloquio verbale? A parte i casi più gravi e quelli più urgenti è ben difficile se non impossibile riconoscere chi vorrebbe ascoltare e parlare e chi invece non aspetta che di ritornare dal suo medico per parlare con lui, ben consapevoli che anche il paziente con un radio- 


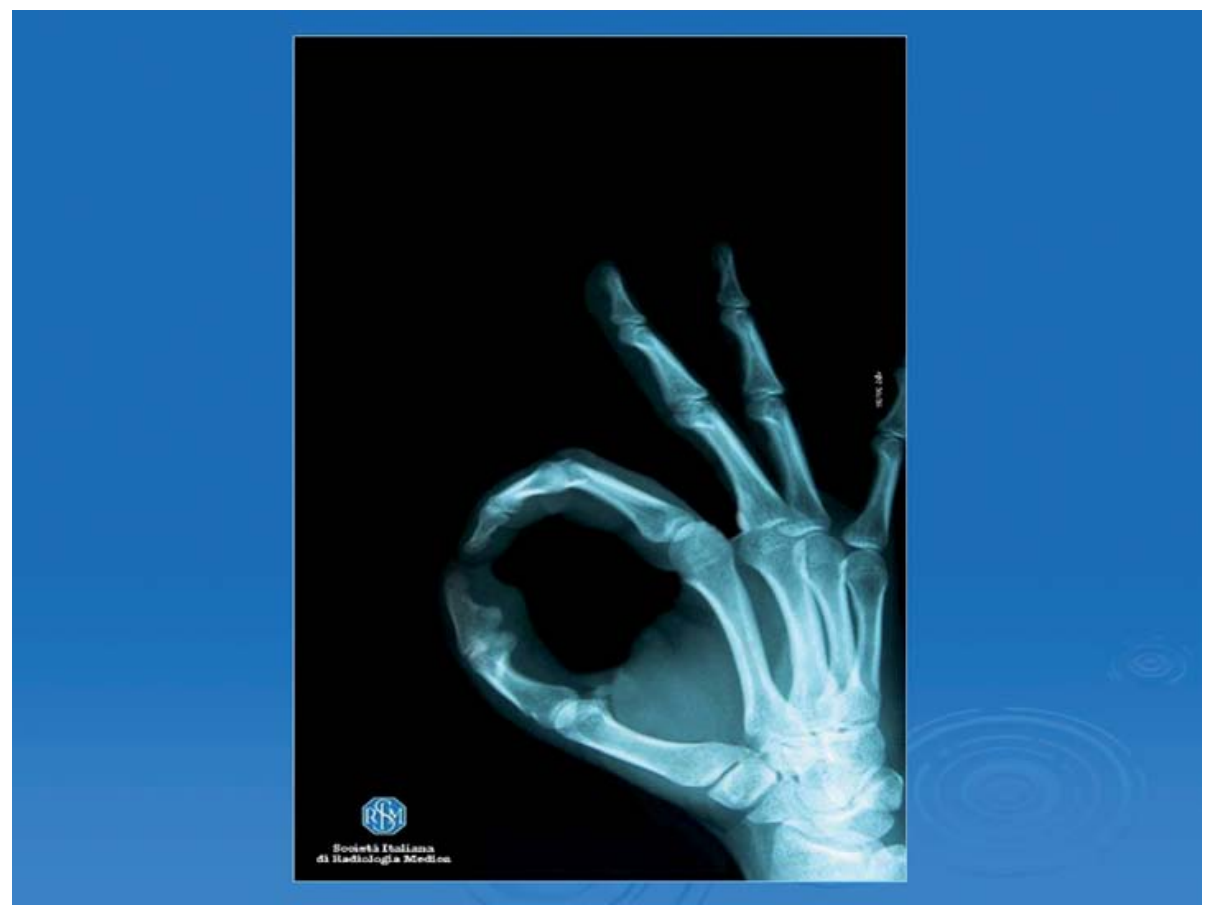

Fig. 1 Your radiologist can provide you with the correct interpretation of your examination and suggest the best diagnostic test for you. All clear! What a relief when the radiology report reassures us about the results of an examination. But why not discuss it with the radiologist? The radiologist is a specialist physician who can guide you as to the most suitable diagnostic pathway for each medical condition. You'll avoid getting lost in the labyrinth of tests that are not always appropriate or necessary. This is why talking to him or her is important (The Italian Society of Medical Radiology).

Fig. 1 Il tuo radiologo può fornirti la corretta interpretazione dell'esame e suggerirti l'indagine diagnostica più idonea. Tutto ok! Che sollievo quando il referto ci tranquillizza sull'esame appena fatto. Ma perché non discuterlo con il medico radiologo? Il medico radiologo è un clinico specializzato che può guidarti nei percorsi diagnostici più idonei per ogni patologia. Eviterai di perderti nel labitinto di indagini non sempre appropriate o necessarie. Ecco perché dialogare con lui è importante (Società Italiana di Radiologia Medica).

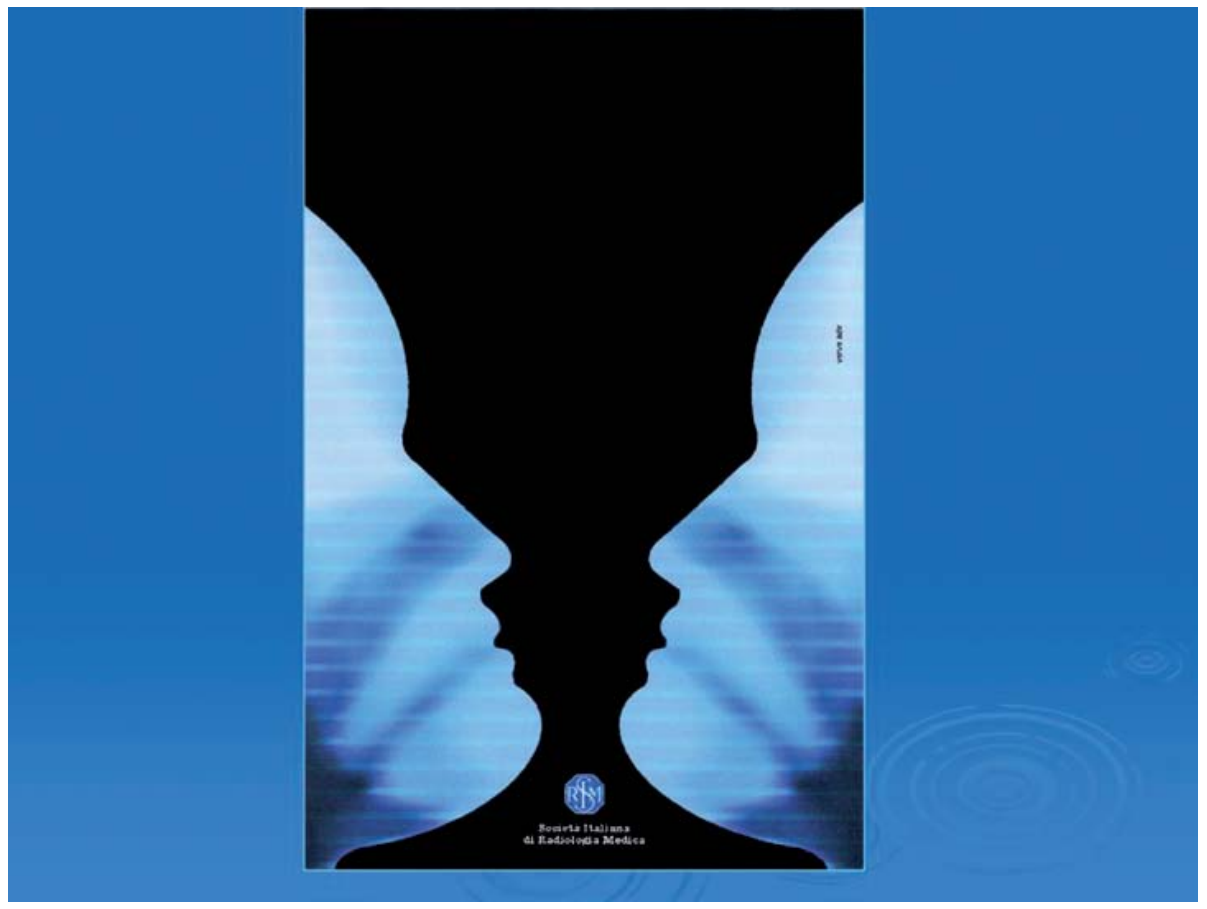

Fig. 2 This X-ray shows something that you rarely see: a dialogue between the patient and a radiologist. Careful interpretation of an X-ray is essential. However, we often just read the diagnosis on the report without discussing it with the radiologist that drew it up. By consulting with your radiologist, you'll avoid getting lost in the labyrinth of investigations that are not always appropriate or necessary. Talk to him or her. That dialogue is really important (The Italian Society of Medical Radiology).

Fig. 2 Questa radiografia evidenzia qualcosa che si vede di rado: il dialogo tra paziente e radiologo. L'esame attento di una radiografia è fondamentale, ma spesso la diagnosi la leggiamo sul referto, senza approfondirlo con il medico radiologo, che lo ha redatto. Incontralo, eviterai di perderti nel labirinto di indagini non sempre appropriate o necessarie. Dialoga con lui, il confronto è davvero importante (Società Italiana di Radiologia Medica).

mind that the patient with a normal chest X-ray often needs to know the value and limitations of the examination, when (or if) it should be repeated, the risks associated with exposure to so many X-rays, and so forth. Currently, the choice made in most areas of diagnostic imaging is to speak with those who need it most, although this choice, while often necessary, excludes many (and all those who have a right to it) from the possibility of a verbal consultation. It should, however, be noted that: gramma toracico normale ha sovente bisogno di conoscere il valore ed i limiti di tale indagine, quando la dovrà eventualmente ripetere, se "si prendono tanti raggi", ecc. Attualmente, la scelta concreta che viene fatta nella gran parte dei servizi di diagnostica per immagini è quella di parlare con chi ne ha maggiormente bisogno, ma con tale scelta pur sovente necessaria si toglie a molti che lo desiderano (e a tutti quegli altri che ne hanno un certo diritto) la possibilità del colloquio verbale. Va però ricordato che: 
- the consultation may be deferred to a later date (a phone number, as recommended in De Santi and Simeone's book on the ideal consultation) or just slightly delayed if this makes it possible;

- it is not strictly necessary that the person reporting on the examination be the same one to engage in the consultation, which may certainly be carried out by a colleague;

- it is important that there is a real possibility of a verbal consultation with the radiologist for each patient who wants one.

A notice listing the radiologist's availability (as seen in every division of care), perhaps accompanied by the posters proposed by the Italian Society of Medical Radiology, ought to be displayed at the entrance to each diagnostic imaging department. This would be helpful both to remind the radiologist of his or her duty to communicate verbally with patients and to teach patients not to flee or ignore (as happens not infrequently) that specialist who can and often wants to communicate numerous things to them.

\section{Conclusions}

I do not think that these simple "musings of an old radiologist" (as I was going to title this short article) about a problem of the past that has become highly relevant today can provide any easy solutions or resolve uncertainties. I do hope, however, that they may help raise awareness of the situation and provide a stimulus for debate in the search for possible and shared solutions.
- il colloquio verbale può essere posticipato (un numero di telefono, come si raccomandava in precedenza nel libro di De Santi e Simeoni [27] a proposito del colloquio ideale) o anche solo differito di poco se questo lo rende possibile;

- non è strettamente necessario che sia l'esecutore del referto ad avere il colloquio verbale con il paziente ma un collega è certamente in grado di supplirlo;

- è importante che vi sia, per ogni paziente che lo desidera, la concreta possibilità del colloquio verbale con il medico radiologo.

Un cartello con una disponibilità oraria dei medici (come avviene in ogni divisione di cura), magari accompagnato dalle figure proposte dalla SIRM è auspicabile possa essere affisso all'ingresso di ogni servizio di diagnostica per immagini. Sarà utile per ricordarci la necessità se non il dovere del colloquio verbale con i pazienti e sarà utile a loro che impareranno a non più sfuggire o ignorare (come oggi non raramente avviene) quello specialista che può e sovente vuole dir loro tante cose.

\section{Conclusioni}

Non penso che queste semplici "considerazioni di un vecchio radiologo" (così avevo intenzione di titolare questo breve articolo) su un problema del passato e oggi più che mai del presente possano indicare facili soluzioni né risolvere incertezze: spero possano essere un'utile presa di coscienza di una realtà ed uno stimolo al dibattito ed alla ricerca di soluzioni possibili e condivise.

\section{Conflict of interest None}

\section{References/Bibliografia}

1. Cardinale AE (2000) Sfera armillare. Idelson-Gnocchi Edizioni, Napoli

2. Dalla Palma L (2006) Il radiologo di domani: quale futuro. Radiol Med 11:621-633

3. Marano P (2008) Formazione e professione del medico radiologo in una società in costante evoluzione. Radiol Med 113:307-318

4. Marano P (2010) Ritorno al paziente. Franco Angeli Edizioni, Milano

5. Berlin L (1977) The radiologist: doctor's doctor or patient's doctor? AJR Am J Roentgenol 128:702-705

6. Berlin L (2002) Communicating findings of radiologic examinations. AJR Am J Roentgenol 178:809-815
7. Berlin L (2007) Communicating results of all radiologic examinations directly to patients: has the time come? AJR Am J Roentgenol 189:1275-1282

8. Berlin L (2009) Communicating results of all outpatient radiologic examinations directly to patients: the time has come. AJR Am J Roentgenol 192:571-573

9. Berquist TH (2009) The needs of the patient come first. AJR Am J Roentgenol 192:557-559

10. Hammerman HJ (2009) Communicating imaging results to patients: on-site results. AJR Am J Roentgenol 192:852-853
11. Levinson W, Roter DL, Mullooly JP (1997) Physician-patient communication: the relationship with malpractice claims. JAMA 277:553559

12. Levitsky DB, Frank MS, Richardson ML (1993) How should radiologists reply when patients ask about their diagnosis. AJR Am J Roentgenol 161:433-436

13. Lorch H, Scherer P (2007) Disclosure of diagnosis in ambulatory radiology practice: expectations of patients and referring physicians. ROFO 179:10431047 
14. Schreiber MH, Leonard M jr, Rieniets CY (1995) Disclosure of imaging findings to patients directly by radiologists: survey of patient's preferences. AJR Am J Roentgenol 167:467-469

15. Schreiber MH (1996) Direct disclosure by radiologists of imaging findings to patients: a survey of radiologists and medical staff members. AJR Am J Roentgenol 167:1091-1093

16. Smith JN, Gunderman RB (2010) Should we inform patients of radiology results? AJR Am J Roentgenol 255:317-321

17. Song HH, Park SH, Hinn KS (1993) Radiologists' responses to patients' inquiry about imaging results. A pilot study on opinions of various groups. Invest Radiol 28:1049-1051
18. Vallely S, Manton Mills JO (1990) Should radiologists talk to patients? Brit Med J 300:305-306

19. Baile WF, Buckman R, Lenzi R et al (2000) SPIKES - A six-step protocol for delivering bad news: application to the patient with cancer. Oncologist 5:302-311

20. Barreau B, Tastet S (2007) L'annonce du diagnostic en sénologie: les techniques de communication. Journal de Radiologie 88:219-223

21. Félicité MC, Marc-Vergnes JP (2007) Une approche cognitive de l'éthique de l'acte d'imagerie médicale. Journal de Radiologie 88:1133-1143

22. Gunderman RB (2001) Patient communication: what to teach radiology residents. AJR 177:41-43
23. Harvey JA, Cohen MA, Brenin DR (2007) Breaking bad news: a primer for radiologists in breast imaging. J Am Coll Radiol 4:800-808

24. Leclère J, Ollivier L, Ruszniewski M, Neuenschwander S (2006) Améliorer la prise en charge des malades en imagerie médicale: le CREDO et les PERLES du radiologue. Journal de Radiologie 87:1831-1836

25. Leclère J, Ollivier L, Dolbeault S, Neuenschwander S (2006) Dialogue entre le radiologue et le patient atteint d'un cancer. Journal de Radiologie 87:99-104

26. Teutsch C (2003) Patient-doctor communication. Med Clin North Am 87:1115-1145

27. De Santi A, Simeoni I (2009) Il medico, il paziente e i familiari. SE Edizioni, Torino 